\title{
Sexual Dysfunction among Women with Diabetes in a Primary Health Care at Semarang, Central Java Province, Indonesia
}

\author{
Lintang Dian Saraswati ${ }^{1}$, Ari Udiyono', Dian Sutrisni², Muh Fauzi ${ }^{3}$
}

\begin{abstract}
${ }^{1}$ Department of Epidemiology Faculty of Public Health Diponegoro University, Semarang, Indonesia, ${ }^{2}$ Women Prison Type II ${ }^{b}$ Kudus, Ministry of Law and Human Rights, Indonesia, ${ }^{3}$ Department of Medical Environmental Biology and Tropical Medicine, School of Medicine, Kangwon National University, South Korea
\end{abstract}

\begin{abstract}
Sexual dysfunction is associated with pain during sexual intercourse. Diabetes mellitus (DM) has been reported to be one of causal factors for sexual dysfunction in women. This cross-sectional study was conducted to describe status of sexual dysfunction in women with DM in the Tlogosari Kulon Primary Health Care, Semarang, Indonesia, in March 2017. A total of 103 women with DM visiting the Primary Health Care participated in this study. Data were collected using a questionnaire-guided interview and through measurements (blood pressure and random blood glucose test). Results showed that $74.8 \%$ of women with DM had sexual dysfunction. The proportion of sexual dysfunction was higher among women in the clinical phase, with uncontrolled blood glucose levels, hypertension grade II, prolonged duration of DM of $\geq 5$ years, undergoing insulin treatment, in menopause, grand multiparity, having used the tubectomy contraception method, low physical activity, depression, and consumption of antihypertensive drugs. Three factors showing an increased tendency to cause sexual dysfunction in women with DM were aging process (Odds Ratio $(\mathrm{OR}): 0.294,95 \% \mathrm{Cl}: 0.072-1.195, \mathrm{p}$-value $=0.087$ ), menopausal status (OR : $0.102,95 \%$ $\mathrm{Cl}: 0.010-1.042, \mathrm{p}$-value $=0.054)$, and consumption of antihypertensive drugs $(\mathrm{OR}: 0.153,95 \% \mathrm{Cl}: 0.033-0.712, \mathrm{p}$-value $=0.170)$. Main factors related to sexual dysfunction were aging process, menopausal status, and consumption of antihypertensive drugs.
\end{abstract}

Keywords: Female sexual function index, pathology, physiology, psychosociology, women with diabetes

\section{Introduction}

Sexual dysfunction is a disorder in terms of desire for sexual satisfaction and the ability to achieve sexual satisfaction. ${ }^{1}$ Sexual dysfunction can have a major impact on the quality of life. ${ }^{2}$ In women, it is a significant reproductive health problem as it is associated with the continuity of a woman's reproductive function and can considerably affect the harmony of the relationship between husband and wife. ${ }^{3}$

The etiology of sexual dysfunction in women is multifactorial and combines interpersonal, contextual (social), psychological (such as depression, anxiety, body image perception disorders, traumatic sexual experience in the past, and history of abuse), and biological factors, including several medical conditions (urogenital, neurological, and endocrine disorders, menopause, pregnancy, and obesity) as well as

How to Cite: Saraswati LD, Udiyono A, Sutrisni D, Fauzi M. Sexual dysfunction among women with diabetes in a primary health center at Semarang, Central Java Province, Indonesia. Kesmas: Public Health Journal. 2019; 14 (2): 95-102. (doi: 10.21109/kesmas.v14i2.2722) pharmacological and other therapies (anti-neoplasmic agents, antipsychotic and antidepressant medications, antihypertensive agents, major surgical operations, radiation therapies). The risk factors for female sexual dysfunction comprising the social and cultural aspects include a lack of social relationships, poverty, employment status, religious life, educational background, and limited sport activity. 4,5

Sexual dysfunction in women with DM is known for a long period of time; however, most studies have not described this condition. 6,7 Moreover, results of several studies on pathogenetic factors of sexual dysfunction still remain controversial. ${ }^{5,8-10}$

One study reported no difference in sexual dysfunction between premenopausal $(62.1 \%)$ and postmenopausal $(62.5 \%)$ women, but a greater incidence of sexual dysfunction was found in women

\footnotetext{
Correspondence $^{*}$ : Lintang Dian Saraswati, Department Epidemiology, Faculty of Public Health, Diponegoro University, C Building 2nd Floor, Prof Soedarto SH street Tembalang, Semarang 50275, Indonesia, Phone: +62-8122916641, E-mail: lintang.saraswati@live.undip.ac.id

Received : October 24th 2018

Revised : February $28^{\text {th }} 2019$

Accepted : September $6^{\text {th }} 2019$
} 
from 50 years of age onward. Age was found to negatively correlate with the female sexual function index (FSFI) score $(\rho=-0.324$, p-value $<0.001) .{ }^{11}$ The prevalence of sexual dysfunction was significantly higher among the study group than in the control group. The study also found that with an increase in blood glucose (HbA1c) levels, body mass index (BMI), and duration of diabetes, the prevalence of sexual dysfunction also increased. 12

The prevalence rates of sexual dysfunction in women with diabetes mellitus (DM) and in the control population have been reported to be $88 \%$ and $80 \%$, respectively. The mean (standard deviation) FSFI score in women with DM was significantly lower than that in the control group (16.2 [9.5] vs. 21 [8.5], p-value = 0.02). DM demonstrated a clear association with the risk of sexual dysfunction in women. ${ }^{13}$ Based on prior study, the negative correlation of age was found to be the most powerful and meaningful to all domains (desire, arousal, lubrication, orgasm, satisfaction, and sexual pain) and total score, followed by the duration of DM. ${ }^{14}$ The mean values for arousal, lubrication, dyspareunia, and orgasm were significantly lower only in the type-1 DM group than in the control group. The mean values for desire were lower in type- 1 and type- 2 DM groups than in the control group. ${ }^{15}$ In another study, the mean values for desire, arousal, lubrication, orgasm, satisfaction, and pain were significantly lower in both type- 1 and type- 2 DM groups than in the control group. ${ }^{13}$ In contrast, one study had reported that the duration of DM showed no association with sexual dysfunction in women with DM among the study population. ${ }^{16}$ Nevertheless, several studies have reported an association between the

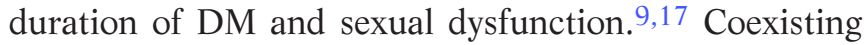
depression has also been reported to have a general link with sexual dysfunction in women with DM. 8,18

Although sexual dysfunction in men due to the complications of DM has been well explained, the sexual problems of women with DM and their relationship with the risk factors still remain less understood and have not received much attention. ${ }^{5}$ On the other hand, sexual dysfunction can have a significant effect on the quality of life. In fact, it is still necessary to investigate the factors associated with sexual dysfunction in women with DM. Based on the above-described information, this descriptive study was conducted to explore the issue of sexual dysfunction in women with DM at a Primary Health Care in Semarang, Central Java Province, Indonesia.

\section{Method}

This descriptive cross-sectional study was conducted to measure the prevalence of sexual dysfunction in women with DM in the Tlogosari Kulon Primary Health
Care, Semarang City, in March 2017. The study population included women with DM who visited the Tlogosari Kulon Primary Health Care in 2016. A total of 158 subjects were recruited using the total sampling method.

The inclusion criteria were female patients with DM diagnosed at the Tlogosari Kulon Primary Health Care and willing to participate in the study. The final study samples included a total of 103 women. A total of 55 subjects had to be excluded from the study, including 29 who did not have spouse, 4 who died, 12 who refused to participate, and 10 subjects who moved. Data were collected through a questionnaire-guided interview. The study protocol was reviewed and approved by the Committee of Public Health Research Ethics, Diponegoro University (No.52/EC/FKM/2017). Informed written consent was obtained from each respondent after providing information about the study.

Women with DM who fulfilled the inclusion criteria were informed about the purpose, benefit, and procedure of this study. Those who agreed to participate were asked for a written informed consent by the interviewer. This was followed by an interview guided by a questionnaire. Demographic data of the participants were collected through FSFI questionnaires, the Beck Depression Inventory (BDI) questionnaires, and Global Physical Activity Questionnaire (GPAQ).

In this study, sexual dysfunction was described on the basis of psychosocial (education level, employment status, and depression status), physiological (age, menopausal status, parity, BMI, and physical activity), pathological (blood sugar level, blood pressure, and duration of diabetes), and pharmacological (type of treatment, antihypertensive drug consumption, and contraceptive method) factors. The total four sections of the questionnaire were divided into 19 questions of FSFI, 21 questions of Beck Depression Inventory-II, and 15 questions of GPAQ that cover the respondents' demographic details, menopausal status, contraception method, duration of diabetes, type of diabetic treatment, and consumption of antihypertensive drugs. Weight, height, blood pressure, and blood sugar levels (random blood sugar test) of the respondents were also measured in this study.

Disorders occur in one or more of the overall normal sexual response cycle. The toal of questions was amounted to 19 pieces. Classification of sexual dysfunction: 1. Desire, No. Question: 1,2, Score range: 1-5, Multiplication factor: 0.6. 2. Arousal No. question: 3,4,5,6, Score range: 0-5, Multiplication factor: 0.3. 3 . Lubrication, No. Question: 7,8,9,10, Score range: 0-5, Multiplication factor: 0.3, 4. Orgasm, No. Question: 11,12,13, Score range: 0-5, Multiplication factor: 0.4, 5. Satisfaction, No. Question: 14,15,16, Score range: 0-5, 
Multiplication factor: 0.4, 6. Sexual pain, No. Question: 17,18,19, Score range: 0-5, Multiplication factor: 0.4. The total score was obtained at a minimum of 1.2 and a maximum score of 36 with a cut-off of 63.6 for each domain and a cut-off of 26.5 for all domains. Thus, the category was termed as sexual dysfunction when the FSFI score was $\leq 26.5$. The variable of stressful work was measured using the International Stress Management Association (ISMA) questionnaire. ${ }^{19}$ According to the ISMA, a person was categorized to have stress if he/she obtained a score was $>14$ points and to have no stress if the score is $<14$ points. Physical activity was measured using the GPAQ.20 Based on the recommendation by WHO, a total physical activity metabolic equivalent turnover (MET) minutes per week of $<600,20$ was classified as low physical activity, 600-1500 MET minutes per week was classified as moderate, and more than 1500-3000 MET minutes per week was classified as vigorous physical activity. Information regarding variables such as the aging process, employment status, education, sexual desire level, consumption of hypertensive and antidepressant drugs, and smoking status was directly collected from the participant using a questionnaire. Obesity was measured using digital weight scales and microtoise, whereas central obesity was measured using Metline. Blood sugar level and duration of diabetes were collected from the patient's medical record data. Variable aging process is a process of disappearing slowly the ability of tissue to repair itself and maintain its normal structure and function, so that it cannot correct the deficiencies suffered. The categories of aging process included the clinical phase (age $\geq 46$ years), the transition phase (age $36-45$ years), and the subclinical phase (age 25 - 35 years). ${ }^{21}$

Multivariate analysis was used to investigate the collected data. Before inputting the data into the logistic model, a bivariate analysis was conducted to assess the aforementioned independent variables. When the chisquare test revealed significant or nearly significant effects ( $p$-value $<0.05$ ), the variable was considered as the predictor in the multiple logistic regression model and stepwise forward and backward procedures were performed. Finally, the goodness-of-fit test (Hosmer and Lemeshow test) was conducted to assess whether the final model was suited to the data. By excluding the least significant variable from the model, a reduction in value was observed, hence that this variable was retained in the model. Odds ratios (OR) were also calculated.

\section{Results}

In Table 1, of the 103 women with DM, $74.8 \%$ had

Table 1. Sexual Function Disorder Domain Based on Female Sexual Function Index Scores

\begin{tabular}{lccc}
\hline & & \multicolumn{2}{c}{ Female Patients with DM } \\
\cline { 3 - 4 } Domain & & f & $\%$ \\
\hline HSDD & $2.3 \pm 1.2$ & 54 & 52.4 \\
FAD & $2.1 \pm 2.0$ & 34 & 33.0 \\
Lubrication & $2.3 \pm 2.2$ & 26 & 25.2 \\
FOD & $2.5 \pm 2.2$ & 22 & 21.4 \\
Satisfaction & $2.5 \pm 2.4$ & 23 & 22.3 \\
SPD & $3.0 \pm 2.7$ & 15 & 14.6 \\
\hline
\end{tabular}

Notes: DM (Diabetes Mellitus), HSDD (hypoactive sexual desire disorder), FAD (female arousal disorder), FOD (female orgasmic disorder), SPD (sexual pain disorder)

Table 2. Distribution of Respondents Based on Psychosocial Factors and Physiological Factors

\begin{tabular}{|c|c|c|c|c|c|}
\hline \multirow{2}{*}{ Factors } & \multirow{2}{*}{ Variable } & \multirow{2}{*}{ Category } & \multirow{2}{*}{$\begin{array}{l}\text { Woman with DM } \\
\quad(\mathrm{n}=103)\end{array}$} & \multicolumn{2}{|c|}{ Sexual Function } \\
\hline & & & & Dysfunction & Normal \\
\hline \multirow[t]{8}{*}{ Psychosocial } & \multirow[t]{4}{*}{ Level of education } & Elementary school & $41(39.8 \%)$ & $33(80.5 \%)$ & $8(19.5 \%)$ \\
\hline & & Junior high school & $24(23.3 \%)$ & $18(75.0 \%)$ & $6(25.0 \%)$ \\
\hline & & Senior high school & $32(31.1 \%)$ & $22(68.8 \%)$ & $10(31.3 \%)$ \\
\hline & & Higher education & $6(5.8 \%)$ & $4(66.7 \%)$ & $2(33.3 \%)$ \\
\hline & \multirow{2}{*}{ Employment status } & Housewife & $75(72.8 \%)$ & $58(77.3 \%)$ & $17(22.7 \%)$ \\
\hline & & Employed & $28(27.2 \%)$ & $19(67.9 \%)$ & $9(32.1 \%)$ \\
\hline & \multirow[t]{2}{*}{ Depression status } & Depression & $27(26.2 \%)$ & $24(88.9 \%)$ & $3(11.1 \%)$ \\
\hline & & Normal & $76(73.8 \%)$ & $53(69.7 \%)$ & $23(30.3 \%)$ \\
\hline \multirow[t]{15}{*}{ Physiological } & \multirow[t]{3}{*}{ Aging process } & Clinical phase & $90(87.4 \%)$ & $71(78.9 \%)$ & $19(21.1 \%)$ \\
\hline & & Transition phase & $8(7.8 \%)$ & $5(62.5 \%)$ & $3(37.5 \%)$ \\
\hline & & Subclinical phase & $5(4.9 \%)$ & $1(20.0 \%)$ & $4(80.0 \%)$ \\
\hline & \multirow{2}{*}{ Menopausal status } & Yes & $75(72.8 \%)$ & $61(81.3 \%)$ & $14(18.7 \%)$ \\
\hline & & No & $28(27.2 \%)$ & $16(57.1 \%)$ & $12(42.9 \%)$ \\
\hline & \multirow{4}{*}{ Parity } & Grand multiparity & $21(20.4 \%)$ & $17(81.0 \%)$ & $4(19.0 \%)$ \\
\hline & & Multiparity & $70(68.0 \%)$ & $56(80.0 \%)$ & $14(20.0 \%)$ \\
\hline & & Primiparity & $9(8.7 \%)$ & $3(33.3 \%)$ & $6(66.7 \%)$ \\
\hline & & Nulliparity & $3(2.9 \%)$ & $1(33.3 \%)$ & $2(66.7 \%)$ \\
\hline & \multirow[t]{3}{*}{ BMI } & Obesity & $52(50.5 \%)$ & $38(73.1 \%)$ & $14(26.9 \%)$ \\
\hline & & Normal & $48(46.6 \%)$ & $37(77.1 \%)$ & $11(22.9 \%)$ \\
\hline & & Underweight & $3(2.9 \%)$ & $2(66.7 \%)$ & $1(33.3 \%)$ \\
\hline & \multirow[t]{3}{*}{ Physical activity } & Light & $8(7.8 \%)$ & $8(100.0 \%)$ & $0(0.0 \%)$ \\
\hline & & Moderate & $81(78.6 \%)$ & $59(72.8 \%)$ & $22(27.2 \%)$ \\
\hline & & Heavy & $14(13.6 \%)$ & $10(71.4 \%)$ & $4(28.6 \%)$ \\
\hline
\end{tabular}

Notes: $\mathrm{BMI}=$ Body Mass Index, DM = Diabetes Mellitus 
sexual dysfunction. The most affected domain was hypoactive sexual desire disorder (HSDD; 52.4\%), whereas the least affected domain was sexual pain disorder (SPD; $14.6 \%$ ).

More than one-third $(39.8 \%)$ of women with DM attending the Tlogosari Kulon Primary Health Care had elementary school level of education (Table 2). The majority of respondents $(72.8 \%)$ were housewives. Regarding the level of depression, most of the respondents $(73.8 \%)$ had normal depression levels. Based on the psychosocial factors, the proportion of sexual dysfunction was higher among those with a primary education $(80.5 \%)$.

Viewed from the perspective of antiaging process, the majority of women aged $>45$ years with DM $(87.4 \%)$ visiting the Tlogosari Kulon Primary Health Care were in the clinical phase (Table 2). More than half of them $(50.5 \%)$ had obesity according to BMI status. The majority of them $(78.6 \%)$ had moderate physical activity. Most women with DM (68.0\%) were included in the multiparity group (2-4 births), and $72.8 \%$ of them had experienced menopause. Based on the physiological factors, the proportion of sexual dysfunction was higher among women with DM in the clinical phase of aging process $(78.9 \%)$, in menopause $(81.3 \%)$, and those with grand multiparity $(81.0 \%)$, normal BMI status $(77.1 \%)$, and low physical activity $(100.0 \%)$.

The majority of women with systolic and diastolic blood pressure were categorized as prehypertensive (46.6\% and $43.7 \%$, respectively, Table 3 ). The proportion of sexual dysfunction was higher among those who had grade II systolic hypertension (94.1\%), and grade II diastolic hypertension $(81.0 \%)$. Most of the women with DM (78.6\%) used oral hypoglycemic agents (OHAs) (Table 4). Regarding contraceptive use, approximately half of the respondents $(48.5 \%)$ had a record of using hormonal contraceptives (pills, injection, and implants).

The majority of study participants $(77.1 \%)$ visiting the Tlogosari Kulon Primary Health Care had diabetes for less than 5 years (Table 5). The longest duration of DM was 21 years, and the shortest was 4 months, with an average duration of 4.3 years. Most of them $(77.8 \%)$ had uncontrolled blood sugar levels (> $200 \mathrm{mg} / \mathrm{dL}$ ), with an average level of $261.6 \mathrm{mg} / \mathrm{dL}$. Moreover, most of them $(65.7 \%)$ did not take antihypertensive drugs. The proportion of sexual dysfunction was higher among those who used insulin $(87.5 \%)$, tubectomy contraceptives $(82.4 \%)$, and antihypertensive drugs $(93.9 \%)$.

Based on multivariate analysis (Table 6), three factors were found to increase the risk for sexual dysfunction in women with DM: aging process ( $\mathrm{p}$-value $=0.087 ; \mathrm{OR}=0.294)$, menopausal status $(\mathrm{p}$-value $=$ 0.054; OR $=0.102)$, and consumption of antihypertensive drugs $(p$-value $=0.170 ; O R=0.153$ ).

Table 3. Distribution of Respondents Based on Pathological Factors

\begin{tabular}{lllrr}
\hline \multirow{2}{*}{ Variable } & Category & $\begin{array}{c}\text { Women } \\
\text { with DM } \\
(\mathbf{n = 1 0 3 )}\end{array}$ & \multicolumn{2}{c}{ Sexual Function } \\
\cline { 5 - 5 } & & & Dysfunction & \multicolumn{1}{c}{ Normal } \\
\hline Systolic blood pressure & Hypertension grade II & $17(16.5 \%)$ & $16(94.1 \%)$ & $1(5.9 \%)$ \\
& Hypertension grade I & $23(22.3 \%)$ & $17(73.9 \%)$ & $6(26.1 \%)$ \\
& Prehypertension & $48(46.6 \%)$ & $34(70.8 \%)$ & $14(29.2 \%)$ \\
& Normal & $15(14.6 \%)$ & $10(66.7 \%)$ & $5(33.3 \%)$ \\
Diastolic blood pressure & Hypertension grade II & $21(20.4 \%)$ & $17(81.0 \%)$ & $4(19.0 \%)$ \\
& Hypertension grade I & $20(19.4 \%)$ & $16(80.0 \%)$ & $4(20.0 \%)$ \\
& Prehypertension & $45(43.7 \%)$ & $32(71.7 \%)$ & $13(28.9 \%)$ \\
& Normal & $17(16.5 \%)$ & $12(70.6 \%)$ & $5(29.4 \%)$ \\
\hline
\end{tabular}

Notes: $\mathrm{DM}=$ Diabetes Mellitus

Table 4. Distribution of Respondents Based on Pharmacological Factors

\begin{tabular}{llrrr}
\hline \multirow{2}{*}{ Variable } & Category & $\begin{array}{c}\text { Woman with DM } \\
(\mathbf{n}=\mathbf{1 0 3})\end{array}$ & Sysfunction & Normal \\
\cline { 4 - 5 } & & $81(78.6 \%)$ & $61(75.3 \%)$ & $20(24.7 \%)$ \\
\hline Type of treatment & OHA & $8(7.8 \%)$ & $7(87.5 \%)$ & $1(12.5 \%)$ \\
& Insulin & $3(2.9 \%)$ & $2(66.7 \%)$ & $1(33.3 \%)$ \\
& OHA + insulin & $11(10.7 \%)$ & $7(63.6 \%)$ & $4(36.4 \%)$ \\
& Diet + exercise & $50(48.5 \%)$ & $38(76.0 \%)$ & $12(24.0 \%)$ \\
Contraceptive method & Hormonal & $17(16.5 \%)$ & $14(82.4 \%)$ & $3(17.6 \%)$ \\
& Tubectomy & $10(9.7 \%)$ & $6(60.0 \%)$ & $4(40.0 \%)$ \\
& IUD & $26(25.2 \%)$ & $19(73.1 \%)$ & $7(26.9 \%)$ \\
\hline
\end{tabular}

Notes: OHA = Oral Hypoglycemic Agents, IUD = Intra-Uterine Device 
Table 5. Association of Independent Variables with Sexual Dysfunction Status among Women

\begin{tabular}{|c|c|c|c|c|c|}
\hline \multirow{2}{*}{ Variable } & \multirow{2}{*}{ Category } & \multicolumn{2}{|c|}{ Sexual Function } & \multirow{2}{*}{ p-Value } & \multirow{2}{*}{ OR $(95 \%$ CI $)$} \\
\hline & & Dysfunction & Normal & & \\
\hline \multirow[t]{2}{*}{ Employment status } & Housewives & $58(77.3 \%)$ & $17(22.7 \%)$ & 0.325 & $1.616(0.61-4.22)$ \\
\hline & Employed & $19(67.9 \%)$ & $9(32.1 \%)$ & & \\
\hline \multirow[t]{2}{*}{ Level of depression } & Depression & $24(88.9 \%)$ & $3(11.1 \%)$ & 0.049 & $3.472(0.95-12.69)$ \\
\hline & Normal & $53(69.7 \%)$ & $23(30.3 \%)$ & & \\
\hline \multirow[t]{2}{*}{ Aging process } & Clinical and transition phase & $76(77.6 \%)$ & $22(22.4 \%)$ & 0.014 & $13.818(1.46-130.07)$ \\
\hline & Subclinical phase & $1(20.0 \%)$ & $4(80.0 \%)$ & & \\
\hline \multirow[t]{2}{*}{ Menopausal status } & Yes & $61(81.3 \%)$ & $14(18.7 \%)$ & 0.012 & $3.268(1.2-6-8.42)$ \\
\hline & No & $16(57.1 \%)$ & $12(42.9 \%)$ & & \\
\hline \multirow[t]{2}{*}{ Parity } & Yes & $76(76.0 \%)$ & $24(24.0 \%)$ & 0.156 & $6.33(0.55-72.9)$ \\
\hline & No & $1(33.3 \%)$ & $2(66.7 \%)$ & & \\
\hline \multirow[t]{2}{*}{ BMI } & Overweight and underweight & $40(72.7 \%)$ & $15(27.3 \%)$ & 0.612 & $0.793(0.32-1.94)$ \\
\hline & Normal & $37(77.1 \%)$ & $11(22.9 \%)$ & & \\
\hline \multirow[t]{2}{*}{ Physical activity } & Low and high & $18(81.8 \%)$ & $4(18.2 \%)$ & 0.390 & $1.678(0.51-5.51)$ \\
\hline & Moderate & $59(72.8 \%)$ & $22(27.2 \%)$ & & \\
\hline \multirow[t]{2}{*}{ Duration of DM } & $\geq 5$ years & $27(77.1 \%)$ & $8(22.9 \%)$ & 0.689 & $1.215(0.46-3.15)$ \\
\hline & $<5$ years & $50(73.5 \%)$ & $18(26.5 \%)$ & & \\
\hline \multirow{4}{*}{$\begin{array}{l}\text { Consumption of } \\
\text { antihypertensive drugs } \\
\text { Blood sugar levels }\end{array}$} & Yes & $31(93.9 \%)$ & $2(6.1 \%)$ & 0.002 & $8.087(1.78-36.7)$ \\
\hline & No & $46(65.7 \%)$ & $24(34.3 \%)$ & & \\
\hline & Uncontrolled & $56(77.8 \%)$ & $16(22.2 \%)$ & 0.282 & $1.667(0.65-4.29)$ \\
\hline & Controlled & $21(67.7 \%)$ & $10(32.3 \%)$ & & \\
\hline \multirow[t]{2}{*}{ Systolic blood pressure } & Hypertension & $67(76.1 \%)$ & $21(23.9 \%)$ & 0.521 & $1.599(0.49-5.19)$ \\
\hline & Normal & $10(66.7 \%)$ & $5(33.3 \%)$ & & \\
\hline \multirow[t]{2}{*}{ Diastolic blood pressure } & Hypertension & $65(75.6 \%)$ & $21(24.4 \%)$ & 0.761 & $1.290(0.40-4.08)$ \\
\hline & Normal & $12(70.6 \%)$ & $5(29.4 \%)$ & & \\
\hline \multirow[t]{2}{*}{ Level of education } & Elementary and high school & $73(75.3 \%)$ & $24(24.7 \%)$ & 0.641 & $1.52(0.26-8.83)$ \\
\hline & Higher education & $4(66.7 \%)$ & $2(33.3 \%)$ & & \\
\hline \multirow[t]{2}{*}{ Contraceptive use } & Yes & $58(75.3 \%)$ & $19(24.7 \%)$ & 0.820 & $1.125(0.41-3.08)$ \\
\hline & No & $19(73.1 \%)$ & $7(26.9 \%)$ & & \\
\hline \multirow[t]{2}{*}{ Contraceptive method } & Tubectomy & $14(82.4 \%)$ & $3(17.6 \%)$ & 0.551 & $1.704(0.44-6.46)$ \\
\hline & Others and none & $63(73.3 \%)$ & $23(26.7 \%)$ & & \\
\hline
\end{tabular}

Notes: $\mathrm{BMI}=$ Body Mass Index, $\mathrm{DM}=$ Diabetes Mellitus, $\mathrm{OR}=$ Odd Ratio, $\mathrm{CI}=$ Confidence Interval

Table 6. Results of Multivariate Analysis

\begin{tabular}{lcc}
\hline Independent Variable & p-Value & OR (95\% CI) \\
\hline Aging process & 0.087 & $0.294(0.072-1.195)$ \\
Menopausal status & 0.054 & $0.102(0.010-1.042)$ \\
Consumption of antihypertensive drugs & 0.170 & $0.153(0.033-0.712)$ \\
\hline
\end{tabular}

Notes: $\mathrm{CI}=$ Confidence Interval, $\mathrm{OR}=$ Odd Ratio

\section{Discussion}

Diabetes causes dysfunctions of blood vessels and nerves, which lead to structural and functional changes in the female genitals, thereby disrupting the sexual responses. Furthermore, hyperglycemia can reduce the hydration of mucous membranes, including the vaginal tissues, causing reduced vaginal lubrication and dyspareunia. Hyperglycemia potentially triggers dyspareunia due to its association with increased incidence of genitourinary infections. ${ }^{5,22}$ The hormonal imbalance accompanying DM also plays a vital role in the pathogenesis of sexual dysfunction in women. Diabetes also causes complications such as blood flow disruptions to sexual organs and hypogonadism, which present as abnormal hypophysical and hypothalamic functions..$^{9,22,23}$ In this study, sexual dysfunction was found in $74.8 \%$ of women with DM, which is consistent with a study in 2015 that reported an incidence of $78.7 \% .{ }^{18}$ However, a later study conducted in 2016 reported an incidence of $55.9 \%$ of sexual dysfunction in women with DM. ${ }^{17}$ Studies have also demonstrated that sexual dysfunction is prevalent in both women and men with DM. ${ }^{6,24,25}$

The results of this study demonstrated that women with DM and grade II hypertension were at risk of developing sexual dysfunction. The higher the blood pressure, the lower the sexual function. This result was consistent with studies conducted in Turkey, which reported that the average FSFI score of women with hypertension (19.6) was lower than that of women without hypertension (22.4), with a significant difference ( $p$-value $=0.012)$. In addition, there was a mean difference in the FSFI scores on the domains of desire, arousal, orgasm, and satisfaction ( $\mathrm{p}$-value $<0.05$ ), 
whereas there was no difference in the average FSFI score on the lubrication and pain domains. ${ }^{17}$ Vascular dysfunction due to hypertension could lead to disruption of blood flow and clitoral function as erectile organs in women. ${ }^{26}$ High blood pressure could be a causal factor for a person's low sexual passion.

However, the use of antihypertensive drugs also has a negative impact on the sexual appetite, especially diuretic medicines and beta-blockers. ${ }^{27}$ These medicines work by reducing and maintaining a low blood pressure when blood flows to the genital organs, which would ultimately inhibit blood flow to the genital organs. Thus, these individuals could experience difficulty in obtaining and maintaining an erection or orgasm, thereby causing sexual dysfunction. ${ }^{28}$ The problem that generally arises in women is the lack of production of vaginal fluids that serve as a lubricant during intercourse. ${ }^{27}$

This study demonstrated that the higher the age, the lower the FSFI score or the sexual function. Persons in the age of the clinical phase ( $>45$ years) were more likely to suffer from sexual dysfunction than those in the subclinical phase and transition phase, which is because in the clinical phase, the presentations of aging begin to be clearly visible, including hair loss, skin wrinkles, high blood pressure, diabetes, heart problems, memory loss, and decreased libido. ${ }^{29,30}$ Several studies have reported that sexual function decreases with age. Increasing age leads to a decrease in testosterone levels, which in turn are associated with decreased sexual desire in both men and women. Thus, the incidence of sexual dysfunction increases with age. ${ }^{31}$ Women in the third phase or the clinical phase are not included in the women of childbearing age category. Women in the women of childbearing age category are defined as those whose reproductive organs functioned well between the age of 20 and 45 years. ${ }^{32}$ In this study, most of the women with DM were not classified in the women of childbearing age category. This result was in accordance with a study conducted in West Jakarta that demonstrated that age affected sexual dysfunction in women. The most dominant variable associated with sexual dysfunction was age ( $\mathrm{p}$-value $=0.007$, OR $=$ 3.45). Elderly people had three times greater risk of developing sexual dysfunction than younger individuals. ${ }^{32}$

In addition, this study has shown that menopausal women with DM tend to suffer from sexual dysfunction compared with women without DM. Women experience major hormonal changes associated with menopause, one among which is a decrease in estrogen levels. In terms of sexual functioning, the major impact of the reduction of estrogen levels is vaginal dryness and atrophy caused due to reduced blood flow, resulting in dyspareunia that in turn causes uncomfortable sexual activity. Besides causing physiological changes such as cessation of fertility, the other effects of menopause include psychological changes that trigger a negative attitude in postmenopausal women and increase their susceptibility to depression. ${ }^{33,34}$ The incidence of sexual dysfunction among postmenopausal women has been reported to be almost $80 \% .35$ This result was consistent with a study conducted in New York City, which reported that the incidence of sexual dysfunction in postmenopausal women was at $70.9 \%$. Another study involving 370 women aged 40-65 years reported that $67 \%$ of them experienced sexual dysfunction and postmenopausal women had two times greater risk for sexual dysfunction than premenopausal women. ${ }^{36}$

A limitation of this study is that there could have been a bias in the information, probably for variables such as sexual function disorder and level of depression, as these variables were directly enquired with the participants using questionnaires at their house in the evening when their spouse was also present. Hence, respondents might have been reluctant to give an honest response regarding their depression status, whether it existed or not, and the sexual function disorders they have. It is also possible that because the interviews were conducted in the afternoon or evening after working hours, the respondents could have answered as needed due to fatigue. The strength of this study is that it reports the proportion of sexual dysfunction among women through which its risk factors can be identified, so that the related authorities can implement promotional and preventive measures.

\section{Conclusion}

In this study, three factors found to increase the risk for sexual dysfunction in women with DM were aging process, menopausal status, and consumption of antihypertensive drugs. The higher the blood pressure, the lower the sexual function in women with DM due to the consumption of antihypertensive drugs, which inhibits blood flow to the genital organs. This study also demonstrated that the higher the age, the lower the FSFI score or the sexual function, because in the clinical phase, the presentations of aging begin to be clearly visible, especially decreased libido. In terms of sexual functioning, the major effects of the reduction of estrogen levels during menopause are the physical and psychological changes, such as the vaginal dryness and atrophy due to reduced blood flow, resulting in dyspareunia that in turn causes uncomfortable sexual activity and might also lead to depression.

Regarding the limitation, the authors clearly state that biased information was inevitable and might affect the results of this study. The cause of the biased information in this study was the involvement of other people who were not respondents in answering the questions; 
however, this could be minimized by inviting the respondents to a place far from the crowd before the interview began.

\section{Acknowledgment}

The authors would like to thank the chief of the Tlogosari Kulon Primary Health Care and all staff for their support to this study. The authors also thank all the respondents for their cooperation in this study. The authors are also grateful to Putri Septyarini for data collection and analysis and also to the Faculty of Public Health, Diponegoro University, for the funding.

\section{References}

1. American Psychiatric Organization. Diagnostic and statistical manual of mental disorder (DSM-IV). American Psychiatric Organization. Washington, DC: American Psychiatric Association; 2012. 1-915.

2. Angelina A, Parlautan A, Putri A, Yuvensia AM, Pratama AN, Falaivi AF, et al. Prevalence of sexual dysfunction based on female sexual function index and perception of newly bride in Jati Village and its related factors. Indonesian Journal Obstetrics and Gynecology [Internet]. 2010 [cited 2018 Feb 26]; 34(4): 231-5. Available from: http://id.portalgaruda.org/?ref=browse \&mod=viewarticle $\&$ article $=30481$

3. Andarmoyo S. Psikoseksual dalam pendekatan konsep dan proses keperawatan. Jogjakarta: Ar-Ruzz Media. 2012: 83-92.

4. Woodard TL, Diamond MP. Physiologic measures of sexual function in women: a review. Fertil Steril [Internet]. 2009 Jul [cited 2019 Jun 22];92(1):19-34. Available from: http://www.ncbi.nlm.nih.gov/pubmed/19046582

5. Bargiota A, Dimitropoulos K, Tzortzis V, Koukoulis GN. Sexual dysfunction in diabetic women. Hormones [Internet]. 2011 [cited 2018 Mar 26];10(3):196-206. Available from: http://www.hormones.gr/pdf/196-206.pdf

6. Esposito K, Maiorino MI, Bellastella G, Giugliano F, Romano M, Giugliano D. Determinants of female sexual dysfunction in type 2 diabetes. International Journal of Impotence Research [Internet]. 2010 [cited 2019 Jun 29]; 22(3): 179-84. Available from: http://www.ncbi.nlm.nih.gov/pubmed/20376056

7. Mohsenpour B, Alizadeh N, Alizadeh N, Arasteh M, Karimian F. Comparison of sexual dysfunction between diabetic and non-diabetic women. Journal of Mid-life Health [Internet]. 2013 [cited 2019 Jun 29]; 4(3): $167 . \quad$ Available from: http://www.ncbi.nlm.nih.gov/pubmed/24672189

8. Giraldi A, Kristensen E. Sexual dysfunction in women with Diabetes Mellitus. Journal of Sex Research [Internet]. 2010 [cited 2018 Feb 26]; 47(2-3): 199-211. Available from: http://www.tandfonline.com/doi/abs/10.1080/00224491003632834

9. Maiorino MI, Bellastella G, Esposito K. Diabetes and sexual dysfunction: current perspectives. Diabetes, Metabolic Syndrome and Obesity [Internet]. 2014 [cited 2019 Jun 22]; 7: 95-105. Available from: http://www.ncbi.nlm.nih.gov/pubmed/24623985

10. Lema VM. Female sexual dysfunction and gynaecological practice: report of six cases. East African Medical Journal [Internet]. 2012 [cited 2019 Jun 29]; 89(9): 312-7. Available from: http://www.ncbi.nlm.nih.gov/pubmed/26852439

11. Carranza-Lira S, Núńez F de DC. Sexual dysfunction prevalence in a group of pre- and postmenopausal Mexican women. Menopausal Review [Internet]. 2018 [cited 2019 Jun 29]; 17(1): 39-42. Available from: http://www.ncbi.nlm.nih.gov/pubmed/29725284

12. Bal MD, Yılmaz SD, Çelik SG, Dinçağ N, Beji NK, Yalçın Ö. Does the Diabetes of type 2 affect the sexual functions of women? Journal of Sex \& Marital Theraphy [Internet]. 2015 [cited 2019 Jun 29]; 41(1): 10713. Available from: http://www.ncbi.nlm.nih.gov/pubmed/24341832

13. Ahmed MR, Shaaban MM, Sedik WF, Mohamed TY. Prevalence and differences between type 1 and type 2 Diabetes Mellitus regarding female sexual dysfunction: a cross-sectional Egyptian study. Journal of Psychosomatic Obstetrics \& Gynecology [Internet]. 2018 [cited 2019 Jun 29]; 39(3): 176-81. Available from: http://www.ncbi.nlm.nih.gov/pubmed/28436753

14. Saraswati, Made Ratna SSF. Disfungsi seksual pada wanita penderita Diabetes Melitus tipe 2. Jurnal Penyakit Dalam. 2011; 12: 92-7.

15. Mazzilli F, Mazzilli R, Imbrogno N, Jlenia E, Delfino M, Bitterman O, et al. Sexual dysfunction in diabetic women: prevalence and differences in type 1 and type 2 Diabetes Mellitus. Diabetes, Metabolic Syndrome and Obesity: Targets and Theraphy [Internet]. 2015 [cited 2019 Jun 29]; 8: 97. Available from: http://www.ncbi.nlm.nih.gov/pubmed/25709482

16. Fatemi SS, Taghavi SM. Evaluation of sexual function in women with type 2 diabetes mellitus. Diabetes and Vascular Disease Research [Internet]. 2009 [cited 2018 Feb 26]; 6(1): 38-9. Available from: http://journals.sagepub.com/doi/10.3132/dvdr.2009.07

17. Tuncel E, Durgun O, Peynirci H, Ersoy C. Sexual dysfunction in female patients with type 2 diabetes mellitus: a cross-sectional single-centre study among Turkish patients. Hum Fertil [Internet]. 2017 [cited 2018 Mar 26]; 20(3): 192-9. Available from: https://www.tandfonline.com/doi/full/10.1080/14647273.2016.1266039

18. Elyasi F, Kashi Z, Tasfieh B, Bahar A, Khademloo M. Sexual dysfunction in women with type 2 Diabetes Mellitus. Iranian Journal of Medical Science [Internet]. 2015 [cited 2018 Feb 26]; 40(3): 206-13. Available from: http://ijms.sums.ac.ir/index.php/IJMS/article/viewFile/1673/406

19. Interanational Stress Management Association (ISMA). Stress questionnaire [Internet]. International Stress Management Association UK. 2013 [cited 2015 Sep 18]: 9-11. Available from: www.isma.org.uk

20. World Health Organization. GPAQ (Global Physical Activity Questionnaire) [Internet]. Surveillance and Population-Based Prevention Prevention of Noncommunicable Diseases Department World Health Organization. [cited 2015 Sep 15]. Available from: www.who.int/chp/steps

21. Dziechciaż M, Filip R. Biological psychological and social determinants of old age: Bio-psycho-social aspects of human aging. Annals of Agric ultural and Environmental Medicine [Internet]. 2014 [cited 2019 May 25]; 21(4): 835-8. Available from: http://www.journalssystem.com/aaem/Biological-psychological-and-social-determinants-of-old-age-Bio-psycho-social-aspects-of-humanaging, 72207,0,2.html

22. Meeking D, Fosbury J, Cummings M. Sexual dysfunction and sexual health concerns in women with diabetes. Practical Diabetes [Internet]. 2013 [cited 2019 Jun 29]; 30(8): 327-31a. Available from: http://doi.wiley.com/10.1002/pdi.1805 
23. Bargiota A, Dimitropoulos K, Tzortzis V, Koukoulis G. Sexual dysfunction in diabetic women. Hormones [Internet]. 2011 [cited 2019 Jun 15];10(3):196-206. Available from: http://www.ncbi.nlm.nih.gov/pubmed/22001130

24. Enzlin P, Rosen R, Wiegel M, Brown J, Wessells H, Gatcomb P, et al. Sexual dysfunction in women with type 1 diabetes: long-term findings from the DCCT/ EDIC study cohort. Diabetes Care [Internet]. 2009 May 1 [cited 2019 Jun 29];32(5):780-5. Available from: http://www.ncbi.nlm.nih.gov/pubmed/19407075

25. Giugliano F, Maiorino M, Bellastella G, Gicchino M, Giugliano D, Esposito K. Determinants of erectile dysfunction in type 2 diabetes. Int J Impot Res [Internet]. 2010 May 11 [cited 2019 Jun 29];22(3):204-9. Available from: http://www.ncbi.nlm.nih.gov/pubmed/20147958

26. Dodie NJ, Tendean L, Wantouw B. Pengaruh lamanya Diabetes Melitus terhadap terjadinya disfungsi ereksi. Jurnal e-Biomedik. 2013; 1(3): 1120-5.

27. Manan E. Bebas dari ancaman disfungsi seksual khusus wanita. 1st ed. Jogjakarta: Buku Biru; 2013.

28. Antou, Edmond K R, Lusiana Satiawati LT. Pengaruh hipertensi terhadap disfungsi ereksi. e-Biomedik. 2014;2(November):1-8.

29. Christoffersen M, Tybjærg-Hansen A. Visible aging signs as risk markers for ischemic heart disease: epidemiology, pathogenesis and clinical implications. Ageing Research Reviews [Internet]. 2016 [cited 2019 Jul 4]; 25: 24-41. Available from: http://www.ncbi.nlm.nih.gov/pubmed/26590331

30. Kizilay F, Gali HE, Serefoglu EC. Diabetes and sexuality. Sexual
Medicine Reviews [Internet]. 2017 [cited 2019 Jul 4]; 5(1): 45-51. Available from: http://www.ncbi.nlm.nih.gov/pubmed/27544297

31. Badan Penelitian dan Pengembangan Kesehatan. Riset Kesehatan Dasar (RISKESDAS) Lap Nas 2013. 2013;1-384.

32. Batlajery J, Hamidah H, Mardiana M. Penggunaan metode kontrasepsi suntikan dmpa berhubungan dengan disfungsi seksual wanita pada akseptor kb suntik. Jurnal Ilmu dan Teknologi Kesehatan [Internet]. 2015; 2(2): 49-56. Available from: http://ejurnal.poltekkesjakarta3.ac.id/index.php/jitek/article/view/46

33. DeLamater J, Karraker A. Sexual functioning in older adults. Current Psychiatry Reports [Internet]. 2009 [cited 2018 Mar 26]; 11(1): 6-11. Available from: http://www.ncbi.nlm.nih.gov/pubmed/19187702

34. Andini D. Hubungan lama menopause dengan kejadian disfungsi seksual pada wanita menopause di posyandu lansia wilayah kerja puskesmas Panjang Bandar Lampung [Internet]. Universitas Lampung; 2015. Available from: http://digilib.unila.ac.id/6407/

35. Ambler DR, Bieber EJ, Diamond MP. Sexual function in elderly women: a review of current literature. Reviews in Obstetrics and Gynecology [Internet]. 2012 [cited 2018 Mar 27]; 5(1): 16-27. Available from: http://www.ncbi.nlm.nih.gov/pubmed/22582123

36. Cabral PUL, Canário ACGMD, Spyrides MHC, Uchôa SA da C, Eleutério Júnior J, Giraldo PC, et al. Physical activity and sexual function in middle-aged women. Rev Assoc Med Bras [Internet]. 2014 [cited 2018 Mar 27];60(1):47-52. Available from: http://www.ncbi.nlm.nih.gov/pubmed/24918852 